\title{
Cell-of-origin classification using the Hans and Lymph2Cx algorithms in primary cutaneous large B-cell lymphomas
}

\author{
Anne M. R. Schrader ${ }^{1}$ (1) Ruben A. L. de Groen ${ }^{2} \cdot$ Rein Willemze $^{3} \cdot$ Patty M. Jansen $^{1} \cdot$ Koen D. Quint ${ }^{3}$. \\ Tom van Wezel ${ }^{1} \cdot$ Ronald van Eijk ${ }^{1}$ - Dina Ruano ${ }^{1}$. Cornelis P. Tensen ${ }^{3}$. Esther Hauben ${ }^{4}$. F. J. S. H. Woei-A-Jin ${ }^{5}$. \\ Anne M. Busschots ${ }^{6} \cdot$ Anke van den Berg $^{7} \cdot$ Arjan Diepstra $^{7} \cdot$ Maarten H. Vermeer $^{3} \cdot$ Joost S. P. Vermaat ${ }^{2}$
}

Received: 24 August 2021 / Revised: 15 December 2021 / Accepted: 28 December 2021 / Published online: 14 January 2022

(c) The Author(s) 2022

\begin{abstract}
Primary cutaneous diffuse large B-cell lymphoma, leg type (PCDLBCL-LT) and primary cutaneous follicle center lymphoma with a diffuse population of large cells (PCFCL-LC) are both primary cutaneous B-cell lymphomas with large-cell morphology (CLBCL) but with different clinical characteristics and behavior. In systemic diffuse large B-cell lymphoma, not otherwise specified (DLBCL-NOS), gene-expression profiling (GEP) revealed two molecular subgroups based on their cell-of-origin (COO) with prognostic significance: the germinal center B-cell-like (GCB) subtype and the activated B-celllike (ABC) subtype. This study investigated whether COO classification is a useful tool for classification of CLBCL. For this retrospective study, 51 patients with PCDLBCL-LT and 15 patients with PCFCL-LC were analyzed for their COO according to the immunohistochemistry-based Hans algorithm and the NanoString GEP-based Lymph2Cx algorithm. In PCFCL-LC, all cases (100\%) classified as GCB by both Hans and Lymph2Cx. In contrast, COO classification in PCDLBCL-LT was heterogeneous. Using Hans, 75\% of the PCDLBCL-LT patients classified as non-GCB and 25\% as GCB, while Lymph2Cx classified only $18 \%$ as ABC, $43 \%$ as unclassified/intermediate, and $39 \%$ as GCB. These COO subgroups did not differ in the expression of BCL2 and IgM, mutations in MYD88 and/or $C D 79 B$, loss of $C D K N 2 A$, or survival. In conclusion, PCFCLLC uniformly classified as GCB, while PCDLBCL-LT classified along the COO spectrum of DLBCL-NOS using the Hans and Lymph2Cx algorithms. In contrast to DLBCL-NOS, the clinical relevance of COO classification in CLBCL using these algorithms has limitations and cannot be used as an alternative for the current multiparameter approach in differentiation of PCDLBCL-LT and PCFCL-LC.
\end{abstract}

Keywords Primary cutaneous diffuse large B-cell lymphoma $\cdot$ Leg type $\cdot$ Primary cutaneous follicle center lymphoma Cell-of-origin $\cdot$ Hans algorithm $\cdot$ Lymph2Cx algorithm

Anne M. R. Schrader

a.m.r.schrader@lumc.nl

1 Department of Pathology, Leiden University Medical Center, P.O. Box 9600, 2300 RC Leiden, The Netherlands

2 Department of Hematology, Leiden University Medical Center, Leiden, The Netherlands

3 Department of Dermatology, Leiden University Medical Center, Leiden, The Netherlands

4 Department of Pathology, University Hospitals Leuven, Leuven, Belgium

5 Department of General Medical Oncology, University Hospitals Leuven, Leuven, Belgium

6 Department of Dermatology, University Hospitals Leuven, Leuven, Belgium

7 Department of Pathology, University Medical Center Groningen, Groningen, The Netherlands

\section{Introduction}

Primary cutaneous diffuse large B-cell lymphoma, leg type (PCDLBCL-LT) and primary cutaneous follicle center lymphoma with a diffuse population of large cells (PCFCL-LC) are both primary cutaneous B-cell lymphomas with largecell morphology (CLBCL), but with different clinical characteristics and behavior [1]. PCDLBCL-LT is an aggressive lymphoma with a 5-year disease-specific survival (DSS) of 56\% despite standard immunochemotherapy (R-CHOP). PCFCL-LC usually has an indolent behavior with a 5-year DSS of $95 \%$ and is preferably treated with local radiotherapy $[1,2]$. PCDLBCL-LT was initially recognized as a subgroup of PCFCL-LC with a somewhat different morphology, typical presentation with skin lesions on the leg(s), and a more 
unfavorable prognosis [3]. In 1997, this resulted in recognition of PCDLBCL-LT as a separate disease entity in the classification system of the European Organization for Research and Treatment of Cancer (EORTC) with differentiation between PCDLBCL-LT and PCFCL-LC being primarily based on clinical criteria (leg vs. non-leg presentation) [4, 5]. With the introduction of the World Health Organization (WHO) -EORTC classification system in 2005, differentiation between both conditions was no longer primarily based on clinical criteria, but on a combination of morphological, immunophenotypical, and clinical criteria [6]. PCFCL-LC shows diffuse infiltrates of large centrocytes (large cleaved cells), no or minimal expression of BCL2 and MUM1, and preferentially presents on the head or trunk. In contrast, PCDLBCL-LT is characterized by the presence of confluent sheets of centroblasts and/or immunoblasts (large noncleaved cells), strong expression of BCL2 and MUM1, and in more than $80 \%$ of cases presents with skin tumors on the leg(s). More recently, expression of IgM, MYD 88 mutations, and loss of $C D K N 2 A$ have been described as new, highly sensitive and/or specific biomarkers favoring a diagnosis of PCDLBCL-LT [7-11]. Using this multiparameter approach, differentiation between PCDLBCL-LT and PCFCL-LC is generally not difficult.

Compared with CLBCL, the classification of nodal/ systemic diffuse large B-cell lymphoma (DLBCL) is more complex. Apart from few more specific anatomical-related subgroups, most cases are classified as DLBCL, not otherwise specified (NOS). In contrast to CLBCL, simple clinical and histological criteria to recognize clinically relevant subgroups in DLBCL-NOS are not available. Gene-expression profiling (GEP) of DLBCL-NOS revealed two major molecular subgroups based on their cell-of-origin (COO) with prognostic significance: the germinal center B-cell-like (GCB) subtype and the activated B-cell-like (ABC) subtype, of which GCB-DLBCL shows a superior survival compared with ABC-DLBCL [12]. However, for this "gold standard" method of GEP, fresh-frozen tissue is needed and this is usually not available in routine diagnostics. Therefore, several alternative methods have been developed as surrogates for COO classification in DLBCL-NOS on formalin-fixed and paraffin-embedded (FFPE) tissue. The most commonly used alternative is the immunohistochemistry-based Hans algorithm that evaluates protein expression of CD10, BCL6, and MUM1 for classification of DLBCL as either GCB or nonGCB subtype [13]. Later, a more accurate and precise alternative for conventional microarray-based GEP was introduced with the Lymph2Cx algorithm using the NanoString (nCounter) technology that is suitable for FFPE tissue [14, 15].

In CLBCL, Hoefnagel et al. [16] demonstrated that there are similarities between PCDLBCL-LT and ABCDLBCL as well as between PCFCL and GCB-DLBCL using conventional array-based GEP. The aim of the present study was to investigate the discriminative performance of $\mathrm{COO}$ classification using the Hans and Lymph2Cx algorithms in a defined group of PCFCL-LC and PCDLBCL-LT.

\section{Materials and methods}

\section{Case selection}

Skin biopsies of 66 patients with a CLBCL, including 51 patients with PCDLBCL-LT and 15 patients with PCFCLLC, were selected from the archives of the Departments of Pathology of the Leiden University Medical Center (LUMC), The Netherlands $(n=60)$, and the University Hospitals Leuven (UZL), Belgium $(n=6)$. Only cases with diffuse infiltrates that were predominantly composed of large B cells were included. Clinical information and follow-up data were collected from the Dutch Registry of Cutaneous Lymphoma and/or from medical records. Thirty-five patients with PCDLBCL-LT and 11 patients with PCFCL-LT were reported in previous studies analyzing immunohistochemical and genetic markers [8, 17]. FFPE skin biopsies were centrally reviewed by AS, PJ, and RW and all patients were diagnosed according to the criteria of the 2016 revision of the WHO classification and the 2018 update of the WHOEORTC classification $[1,18]$. At time of diagnosis, presence of extracutaneous disease was excluded by standard staging procedures, consisting of a fluorodeoxyglucose positron emission tomography-computed tomography (FDG PETCT) scan or a CT scan in combination with a bone marrow biopsy.

\section{Immunohistochemistry}

Immunohistochemistry (IHC) was performed with the Dako Autostainer Link 48, according to the manufacturer's recommendations, for the antibodies CD10 (clone 56C6 from Dako, diluted 1:20), BCL6 (clone PG-B6p from Invitrogen, diluted 1:100), MUM1 (clone MUM1p from Dako, diluted 1:100), BCL2 (clone 124 Dako, diluted 1:80), and IgM (polyclonal, from Dako, diluted 1:500). The markers were scored positive in case of expression in $\geq 30 \%$ of the tumor cells for CD10, BCL6, and MUM1, and in $\geq 50 \%$ of the tumor cells for BCL2 and IgM.

\section{Molecular analysis}

For molecular analysis, DNA and mRNA were isolated with the Tissue Preparation System (TPS) robot (Siemens Healthcare Diagnostics) from $10 \mu \mathrm{m}$ microdissected sections of FFPE tissue blocks that contained $\geq 60 \%$ tumor cells, as described previously [19]. For GEP with NanoString, in 
total, 150 ng (range 100 to $200 \mathrm{ng}$ ) of RNA per sample was used. The resulting raw counts obtained by NanoString gene-expression analysis were uploaded at the Lymphoma/ Leukaemia Molecular Profiling Project (LLMPP) website for COO categorization (https://lmpp.nih.gov/LYMPHCX/index. shtml) [15]. The Lymph2Cx panel evaluates the expression of 20 genes: 7 ABC-related genes (TNFRSF13B, LIMD1, IRF4, CREB3L2, PIM2, CYB5R2, RAB7L1, and CCDC50), 8 GCBrelated genes (MME, SERPINA9, ASB13, MAML3, ITPKB, $M Y B L 1$, and $S 1 P R 2$ ), and 5 housekeeping genes for normalization (R3HDM1, WDR55, ISY1, UBXN4, TRIM56). Cases with a normalization of the housekeeping genes below 20 were excluded from further analysis because of poor quality of the sample $(n=0)$. The weight of all genes was analyzed and a probability score between 0 and 1 was generated, as described by Scott et al. [15]. A probability score $\leq 0.1$ indicated classification as GCB, 0.11 to 0.89 as unclassified/intermediate (UI), and $\geq 0.90$ as $\mathrm{ABC}$.

In addition to GEP, the general molecular profile was determined via targeted next-generation sequencing (tNGS) with the LYMFv1 panel including 52 B-cell lymphoma-related genes, according to the methods described in a previous study [20]. The complete molecular profile of PCDLBCL-LT and PCFCL-LC was included in Supplemental Fig. 1. For the purpose of the current study, only the mutational status of MYD88 and $C D 79 B$ and loss of $C D K N 2 A$ were reported.

\section{Statistical analysis}

Comparison of the characteristics between the COO subgroups was performed with the $\chi^{2}$ test for categorical variables and the Kruskal-Wallis test for continuous variables. The overall survival (OS) and DSS were estimated with the cumulative proportion surviving at the end of 5 years of follow-up duration. In time-to-event analysis, the starting point was the date of the histological diagnosis. An event was defined as death by any cause for OS and death by lymphoma/lymphoma-related death for DSS. Patients without an event at the last time of follow-up were censored. Risk groups were compared with the log-rank test. Median follow-up duration was calculated with the reverse Kaplan-Meier method [21]. Statistical analyses were performed with IBM SPSS Statistics 25. A $p$-value of $<0.05$ was considered statistically significant.

\section{Results}

The clinical characteristics and follow-up data, immunohistochemistry, genetic alterations, and the results of $\mathrm{COO}$ classification of the 51 PCDLBCL-LT and 15 PCFCL-LC are presented in Table 1, Fig. 1, and Supplemental Fig. 1.

\section{Clinical characteristics}

Patients with PCDLBCL-LT included 26 females and 25 males. The median age at diagnosis was 78 (range, 47 to 92) years. Forty-three of 51 (84\%) patients presented with skin lesions on one or both legs. In the remaining patients, disease was located on the upper lip $(n=1)$, cheek $(n=1)$, abdomen $(n=1)$, arm $(n=3)$, hip $(n=1)$, and penis $(n=1)$. Initial therapy with multiagent chemotherapy ( $n=21$ with rituximab and $n=5$ without rituximab) or radiotherapy $(n=23)$ resulted in a complete remission in 48 of $49(98 \%)$ cases. In two patients, no treatment was given because of spontaneous remission of the skin lesions $(n=1)$ or sudden unrelated death $(n=1)$. After a median follow-up of 11.3 (range, 0.17 to 16.3 ) years, 20 patients were still alive with $(n=8)$ or without $(n=12)$ evidence of disease, 16 patients had died of lymphoma, and 15 patients had died of unrelated disease. At 5 years, the overall survival was $48 \%$ and the disease-specific survival was $59 \%$.

Patients with PCFCL-LC included four females and 11 males with a median age at diagnosis of 58 (range, 37 to 67) years. Fourteen of 15 (93\%) patients presented with (localized) skin lesions in the head-and-neck region and/or trunk. The remaining patient presented with skin lesions on the right arm and left leg. Initial treatment consisted of radiotherapy and resulted in a complete remission in all patients. After a median follow-up of 7.0 (range, 4.3 to 16.1) years, all 15 patients were alive with $(n=8)$ or without $(n=7)$ evidence of disease.

\section{Histopathology and immunohistochemistry}

PCDLBCL-LT showed diffuse infiltrates of centroblasts and/ or immunoblasts (large non-cleaved cells), which expressed BCL2 in 48 of 51 (94\%), MUM1 in 42 of 51 (82\%), and IgM in 46 of 49 (94\%) cases (Fig. 1). PCFCL-LC consisted of diffuse populations of large centrocytes (large cleaved cells). In contrast to PCDLBCL-LT, BCL2 and IgM were expressed in only one of 15 (7\%) cases each, while MUM1 staining was negative in all cases.

\section{Hans algorithm}

In PCDLBCL-LT, the immunohistochemical markers of the Hans algorithm, CD10, BCL6, and MUM1, showed expression in 7 of $51(14 \%), 34$ of $51(67 \%)$, and 42 of $51(82 \%)$ patients, respectively (Fig. 1). As most cases expressed MUM1 and were negative for CD10, the majority (38/51; $75 \%$ ) was classified as non-GCB. In the remaining 13 cases (25\%), GCB classification was attributed to the expression of CD10 in seven patients and isolated expression of BCL6 


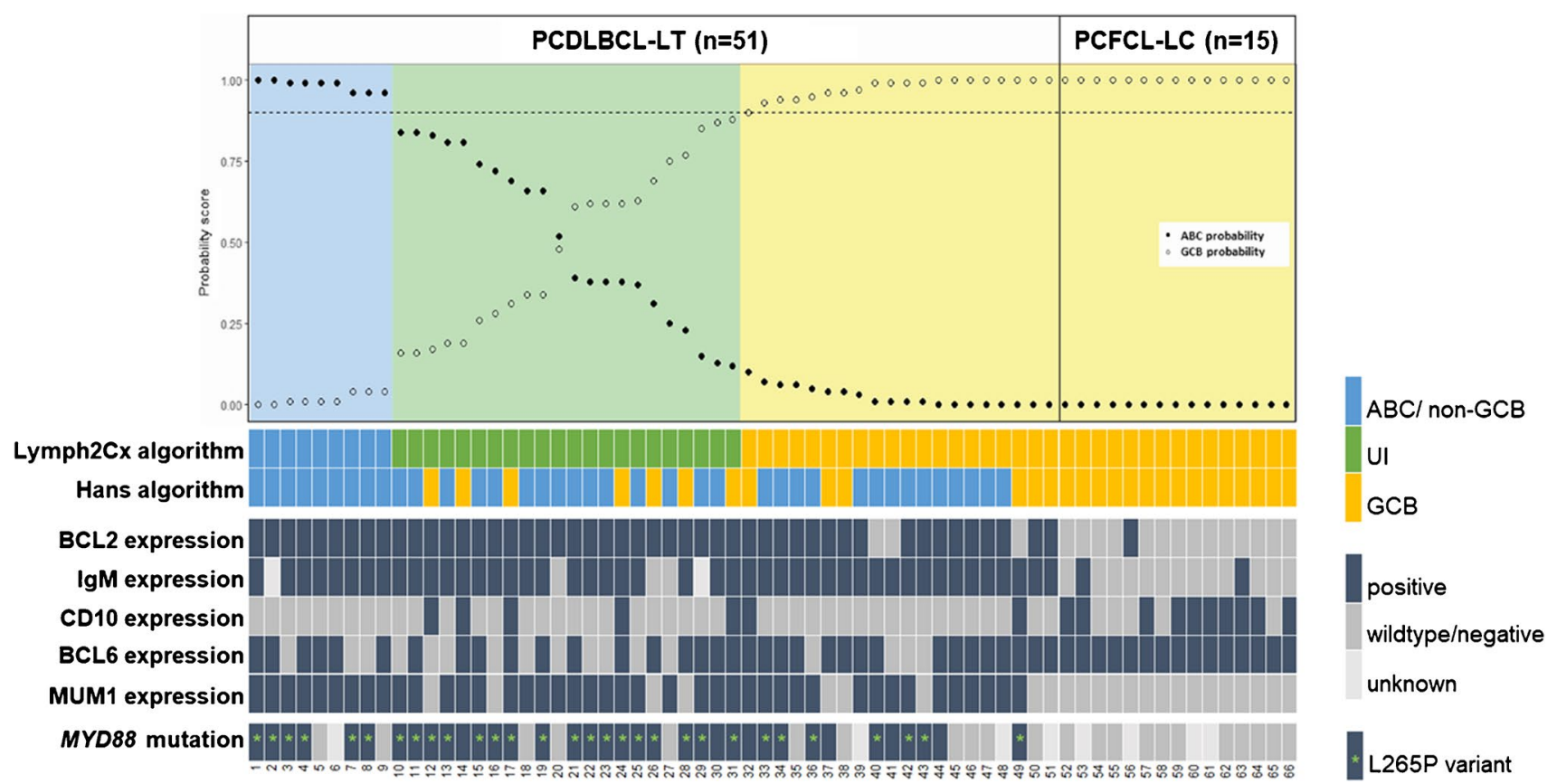

Fig. 1 OncoPrint of cell-of-origin (COO) classification, immunohistochemistry, and MYD88 status in 51 cases with primary cutaneous diffuse large B-cell lymphoma, leg type (PCDLBCL-LT) and 15 cases of primary cutaneous follicle center lymphoma with a diffuse population of large cells (PCFCL-LC). The Hans and Lymph2Cx algorithms were fully concordant in the PCFCL-LC cases $(15 / 15$; $100 \%)$ but were discordant in the majority $(36 / 51 ; 71 \%)$ of the cases with PCDLBCL-LT. The majority of PCDLBCL-LT cases expressed BCL2 $(94 \%), \operatorname{IgM}(94 \%)$, and MUM1 $(82 \%)$, while expression of BCL2 (7\%), IgM (7\%), and MUM1 (0\%) was absent or only rarely present in PCFCL-LC. Mutations in MYD88 were detected in 36 of $47(77 \%)$ of PCDLBCL-LT but in none of $11(0 \%)$ PCFCL-LC cases.

in six patients. Comparison between PCDLBCL-LT cases classified as either non-GCB or GCB showed no differences in the expression of BCL2 and IgM as well as in survival.

In the PCFCL-LC group, all patients $(15 / 15 ; 100 \%)$ were classified as GCB subtype. This was attributed to both CD10 and BCL6 expression in eight patients and to isolated BCL6 expression in seven patients. None of the cases expressed MUM1.

\section{Gene-expression profiling}

\section{Lymph2Cx algorithm}

In contrast to the Hans algorithm, $\mathrm{COO}$ classification of the PCDLBCL-LT patients with the Lymph2Cx panel identified only nine of 51 (18\%) patients as ABC subtypes (Fig. 1). The other cases were classified as GCB $(20$ of $51 ; 39 \%)$ or as UI ( 22 of $51 ; 43 \%$ ). The Lymph 2 Cx prediction scores ranged between 0.00 and 1.00. Regarding the patient characteristics, immunohistochemistry, MYD88 and $C D 79 B$ mutations, loss of $C D K N 2 A$, and survival of the PCDLBCL-LT patients,
There was no statistically significant difference for the frequency of BCL2 or IgM expression and MYD88 mutations between the COO subgroups as defined by Hans or Lymph2Cx in PCDLBCL-LT. Remark: A probability score $\leq 0.1$ indicated classification as GCB, 0.11 to 0.89 as unclassified, and $\geq 0.90$ as $\mathrm{ABC}$.[15]. Abbreviations: PCDLBCL-LT, primary cutaneous diffuse large B-cell lymphoma, leg type; PCFCL-LC, primary cutaneous follicle center lymphoma with a diffuse population of large cells; $\mathrm{ABC}$, activated B-cell-like subtype; GCB, germinal center B-cell-like subtype; UI, unclassified/ intermediate. *MYD88 non-L265P mutations consisted of S234N $(n=4), \mathrm{Y} 240 \mathrm{~S}(n=1)$, and M232T $(n=1)$

there were no statistically significant differences between the three $\mathrm{COO}$ subgroups. All nine patients in the ABC subgroup were also classified as non-GCB by the Hans algorithm ( $100 \%$ concordance), but in the GCB category, classification of only six of 20 (30\%) patients was concordant. The UI category consisted of a mixture of cases classified as non-GCB $(15 / 22 ; 68 \%)$ and GCB $(7 / 22 ; 32 \%)$ by Hans.

In the PCFCL-LC group, COO classification with the Lymph2Cx algorithm was fully concordant with the Hans algorithm and all 15 patients were classified as GCB subtypes. Their prediction scores were all determined at 0.00 .

\section{Genetic profile}

The results of mutational analysis with our 52-gene panel are presented in Supplementary Fig. 1 for the PCDLBCLLT and Supplementary Fig. 2 for the PCFCL-LC. Thirtysix of 47 (77\%) PCDLBCL-LT patients harbored a MYD88 mutation, including the hotspot L265P in 30 (83\%) of these patients, and 22 of 47 (47\%) patients had a $C D 79 B$ mutation, with the hotspot Y196 mutation in 13 (59\%) of these cases. 
Table 1 Patient characteristics and overview of results of cell-or-origin classification with the Hans and Lymph2Cx algorithms in patients with primary cutaneous large B-cell lymphomas

\begin{tabular}{|c|c|c|c|c|c|c|c|c|c|}
\hline \multirow{3}{*}{$\begin{array}{l}\text { Character- } \\
\text { istics }\end{array}$} & \multirow{3}{*}{$\begin{array}{l}\text { PCFCL-LC } \\
\text { All cases/all } \\
\text { GCB } \\
(n=15)\end{array}$} & \multicolumn{8}{|c|}{ PCDLBCL-LT } \\
\hline & & \multirow{2}{*}{$\begin{array}{l}\text { All cases } \\
(n=51)\end{array}$} & \multicolumn{3}{|l|}{ Lymph2Cx } & \multirow[t]{2}{*}{$p$-value ${ }^{\mathrm{a}}$} & \multicolumn{2}{|l|}{ Hans } & \multirow[t]{2}{*}{$p$-value } \\
\hline & & & $\begin{array}{l}\mathrm{ABC} \\
(n=9)\end{array}$ & $\begin{array}{l}\mathrm{UI} \\
(n=22)\end{array}$ & $\begin{array}{l}\mathrm{GCB} \\
(n=20)\end{array}$ & & $\begin{array}{l}\text { non-GCB } \\
(n=38)\end{array}$ & $\begin{array}{l}\mathrm{GCB} \\
(n=13)\end{array}$ & \\
\hline $\begin{array}{c}\text { Female gen- } \\
\text { der, } n(\%)\end{array}$ & $4(27)$ & $26(51)$ & $6(67)$ & $9(41)$ & $11(55)$ & 0.39 & $23(61)$ & $3(23)$ & 0.020 \\
\hline $\begin{array}{l}\text { Median age at } \\
\text { diagnosis, } \\
\text { year (range) }\end{array}$ & $58(37-67)$ & $78(47-92)$ & $80(47-86)$ & 77 (49-86) & $79(53-92)$ & 0.77 & 79 (47-92) & $77(56-86)$ & 0.27 \\
\hline $\begin{array}{l}\operatorname{Leg}(\mathrm{s}) \\
\text { involved at } \\
\text { diagnosis, } \\
n(\%)\end{array}$ & $1(7)^{b}$ & $43(84)$ & $7(78)$ & $19(86)$ & $17(85)$ & 0.83 & $32(84)$ & $11(85)$ & 0.97 \\
\hline Initial therapy & & & & & & 0.17 & & & 0.32 \\
\hline $\begin{array}{l}\text { Local radio- } \\
\text { therapy }\end{array}$ & $15(100)$ & $23(45)$ & $1(11)$ & $12(55)$ & $10(50)$ & & $15(39)$ & $8(62)$ & \\
\hline $\begin{array}{l}\text { (Immuno) } \\
\text { chemothera- } \\
\text { py }^{\mathrm{c}}\end{array}$ & 0 & $26(51)$ & $8(89)$ & $9(41)$ & $9(45)$ & & $21(55)$ & $5(38)$ & \\
\hline None $^{\mathrm{d}}$ & 0 & $2(4)$ & 0 & $1(5)$ & $1(5)$ & & $2(5)$ & 0 & \\
\hline $\begin{array}{l}\text { Median } \\
\text { follow-up } \\
\text { duration, } \\
\text { years } \\
\text { (range) }\end{array}$ & $7.0(4.3-16.1)$ & $\begin{array}{l}11.3(0.17- \\
16.3)\end{array}$ & $\begin{array}{l}11.3 \\
\quad(0.6-11.3)\end{array}$ & $\begin{array}{c}6.9(0.6- \\
13.4)\end{array}$ & $\begin{array}{l}12.1(0.17- \\
16.3)\end{array}$ & 0.58 & $\begin{array}{l}9.9(0.17- \\
16.3)\end{array}$ & $\begin{array}{l}11.3 \\
\quad(2.0-13.0)\end{array}$ & 0.61 \\
\hline $\begin{array}{l}\text { 5-year overall } \\
\text { survival, } \%\end{array}$ & 100 & 48 & 29 & 48 & 58 & 0.38 & 43 & 59 & 0.43 \\
\hline $\begin{array}{l}\text { 5-year } \\
\text { disease- } \\
\text { specific } \\
\text { survival, \% }\end{array}$ & 100 & 59 & 33 & 61 & 69 & 0.36 & 51 & 81 & 0.14 \\
\hline \multicolumn{10}{|l|}{$\begin{array}{l}\text { Immunohisto- } \\
\text { chemistry }\end{array}$} \\
\hline BCL2 & $1(7)$ & $48(94)$ & $9(100)$ & $22(100)$ & $17(85)$ & 0.09 & $36(95)$ & $12(92)$ & 0.75 \\
\hline $\operatorname{IgM}$ & $1(7)$ & $46(94)^{f}$ & $8(89)^{\mathrm{e}}$ & $18(82)$ & $20(100)$ & 0.12 & $34(89)^{\mathrm{f}}$ & $12(92)$ & 0.78 \\
\hline CD10 & $9(60)$ & $7(14)$ & 0 & $5(23)$ & $2(10)$ & 0.21 & 0 & $7(54)$ & 0.000 \\
\hline BCL6 & $15(100)$ & $34(67)$ & $6(67)$ & $12(55)$ & $16(80)$ & 0.22 & $22(58)$ & $12(92)$ & 0.023 \\
\hline MUM1 & 0 & $42(82)$ & $9(100)$ & $18(82)$ & $15(75)$ & 0.26 & $36(95)$ & $6(46)$ & 0.000 \\
\hline \multicolumn{10}{|l|}{$\begin{array}{l}\text { Genetic } \\
\text { profile }\end{array}$} \\
\hline $\begin{array}{l}\text { MYD88 muta- } \\
\text { tion }\end{array}$ & $0^{\mathrm{h}}$ & $36(77)^{\mathrm{h}}$ & $6(75)^{\mathrm{e}}$ & $19(86)$ & $11(55)^{\mathrm{g}}$ & 0.28 & $26(74)^{\mathrm{g}}$ & $10(83)^{\mathrm{e}}$ & 0.52 \\
\hline $\begin{array}{l}\text { Hans algo- } \\
\text { rithm }\end{array}$ & & & & & & 0.15 & & & \\
\hline Non-GCB & 0 & $38(75)$ & $9(100)$ & $15(68)$ & $14(70)$ & & $38(100)$ & NA & NA \\
\hline GCB & $15(100)$ & $13(25)$ & 0 & $7(32)$ & $6(30)$ & & NA & $13(100)$ & \\
\hline $\begin{array}{r}\text { Lymph2Cx } \\
\text { algorithm }\end{array}$ & & & & & & NA & & & 0.15 \\
\hline $\mathrm{ABC}$ & 0 & $9(18)$ & $9(100)$ & NA & NA & & $9(24)$ & 0 & \\
\hline UI & 0 & $22(43)$ & NA & $22(100)$ & NA & & $15(41)$ & $7(50)$ & \\
\hline GCB & $15(100)$ & $20(39)$ & NA & NA & $20(100)$ & & $14(37)$ & $6(46)$ & \\
\hline
\end{tabular}

Abbreviations: $P C F C L-L C$, primary cutaneous follicle center lymphoma with a diffuse population of large cells; $P C D L B C L-L T$, primary cutaneous diffuse large B-cell lymphoma, leg type; $G C B$, germinal center B-cell-like; $A B C$, activated B-cell-like; $U I$, unclassified/intermediate; $N A$, not applicable

${ }^{a} \chi^{2}$ test for categorical data, the Mann-Whitney $U$ or Kruskal Wallis test for continuous variables in case of the Hans algorithm (2 groups) or the 
Table 1 (continued)

Lymph2Cx algorithm (3 groups), respectively, and log-rank for survival analysis. Bold values are statistically significant

${ }^{\mathrm{b}}$ This patient presented with skin lesions on the right arm and left leg

c(Immuno)chemotherapy consisted of R-CHOP, CHOP, or (R)CHOP-like regimens, such as R-CEOP. From the patients who received (immuno) chemotherapy, 21 (81\%) patients received regimens with rituximab and five (19\%) patients, all diagnosed between 2001 and 2005 , received regimens without rituximab

${ }^{\mathrm{d}}$ No therapy was given because of spontaneous remission of the skin lesions $(n=1)$ and sudden unrelated death $(n=1)$

${ }^{\mathrm{e}}$ Data is missing in one case

${ }^{\mathrm{f}}$ Data is missing in two cases

${ }^{\mathrm{g}}$ Data is missing in three cases

${ }^{\mathrm{h}}$ Data is missing in four cases

Loss of $C D K N 2 A$ was identified in 29 of 47 (62\%) cases. In our cohort of PCDLBCL-LT, MYD88, and/or CD79B mutations as well as loss of $C D K N 2 A$ were present in all $\mathrm{COO}$ subtypes, either defined by Hans or the Lymph2Cx algorithm, without a statistical difference (data not shown). None of the successfully analyzed PCFCL-LC patients $(n=11)$ harbored a MYD 88 or $C D 79 B$ mutation.

\section{Discussion}

Diagnosis of CLBCL is primarily made on a combination of the clinical presentation and the morphology and immunophenotype of the tumor cells (supported by specific molecular markers). In order to determine the discriminative performance of $\mathrm{COO}$ classification in CLBCL, this study describes the results of the IHC-based Hans algorithm and the GEP-based Lymph2Cx algorithm in 66 patients with a CLBCL, including 51 patients with PCDLBCL-LT and 15 patients with PCFCL-LC.

All cases of PCFCL-LC were uniformly classified as GCB by both the Hans algorithm and the Lymph2Cx algorithm. These results correspond to literature with GCB classification of PCFCL-LC in 23 of 25 (92\%) cases using Hans and in all ten (100\%) PCFCL cases with spindle-cell morphology using NanoString technology [22, 23].

In contrast to the homogeneous results in PCFCL-LC, the results of COO classification in PCDLBCL-LT patients were heterogeneous. Using Hans, $75 \%$ of the PCDLBCL-LT patients classified as non-GCB and $25 \%$ as GCB. However, using the Lymph $2 \mathrm{Cx}$ algorithm, only $18 \%$ of the cases was classified as ABC, while 39\% was determined as GCB and $43 \%$ as UI.

Regarding the Hans algorithm, our results correspond roughly to a study reporting non-GCB classification in 14 of $23(61 \%)$ PCDLBCL-LT patients [24]. In another study, however, all 32 PCDLBCL-LT cases (100\%) had a nonGCB phenotype [22]. In this latter study, CD10 expression, a key marker of the Hans algorithm, was used as an exclusion criterion for diagnosis of PCDLBCL-LT. Although
CD10 expression is uncommon in PCDLBCL-LT, it has never been used as an exclusion criterion for diagnosis of PCLDBCL-LT $[18,25]$. In our cohort of PCDLBCL-LT, all CD10-positive cases showed the characteristic features of PCDLBCL-LT, including presentation on the leg(s), roundcell morphology, lack of (residual) follicular dendritic cellnetworks, expression of BCL2 and MUM1 in all but one case, IgM expression in all cases, and MYD88 mutations in all cases. In addition, there was no difference in survival between the CD10-positive and CD10-negative PCDLBCLLT cases (OS: $57 \%$ vs. $46 \%$, log-rank 0.69; DSS: $69 \%$ vs. $57 \%, \log$-rank $p$-value 0.67 ). Therefore, there is no reason to use CD10 expression for exclusion as PCDLBCL-LT.

Regarding the Lymph2Cx algorithm, no studies specifically using this technique in PCDLBCL-LT patients have been published so far. Interestingly, the percentage of ABC-classified cases (18\%) of PCDLBCL-LT in our cohort is much lower than expected based on the similarities in GEP of PCDLBCL-LT with ABC-DLBCL and PCFCL-LC with GCB-DLBCL, as described by Hoefnagel et al. [16]. Also, the immune phenotype of PCDLBCLLT is characterized by protein expression of the activated B-cell markers BCL2, MUM1, and IgM in the vast majority of the patients. Accordingly, the genetic profile is dominated by $\mathrm{NF \kappa B}$-activating mutations, predominantly in $M Y D 88$ and $C D 79 B$, which are enriched in ABC-DLBCL and, especially, primary central nervous system lymphoma (PCNSL), primary testicular lymphoma (PTL), and intravascular large B-cell lymphoma [26-28]. In contrast, the GCB marker BCL6 is commonly expressed [2] and a significant subgroup of PCDLBCL-LT harbors $M Y C$ rearrangements $[17,29]$, generally seen as an early GC event [30]. In PCNSL and PTL, 60 to $96 \%$ is classified as nonGCB by the Hans algorithm, corresponding to our results (75\%) in PCDLBCL-LT [31-34]. However, Bödör et al. [31] identified a much higher percentage of $\mathrm{ABC}$ cases defined by Lymph2Cx in 77 PCNSL cases (81\%) compared with PCDLBCL-LT in our study (18\%). On the other hand, Montesinos et al. [35] also demonstrated heterogeneity in GEP profiles in 21 PCNSL cases, as $24 \%$ classified as 
$\mathrm{ABC}, 33 \%$ as $\mathrm{GCB}$, and $43 \%$ as UI using the $\mathrm{COO}$ algorithm developed by Wright et al. [36]. In addition, a study using microarray-based GEP in 23 PCNSL cases demonstrated overlapping expression of germinal-center and activated $\mathrm{B}$-cell genes [37]. In line with these findings, recent studies in DLBCL-NOS also demonstrated that binary classification into $\mathrm{ABC}$ or $\mathrm{GCB}$ does not correspond to the more complex biology as identified by transcriptomics and that recurrent genetic alterations are identified beyond the established COO subtypes [38-40].

The discrepancy in results of $\mathrm{COO}$ classification in PCDLBCL-LT may partly be clarified by the significantly different techniques and diverse selection of genes used for classification. The analysis of Hoefnagel et al. [16] was based on 43 discriminating genes, of which only 3 genes (IRF4, ITPKB, and PIM2) overlapped with the genes in the Lymph2Cx panel. In addition, their study did not address the UI category, as was determined in $43 \%$ of our PCDLBCLLT cases. Nevertheless, the poor correspondence and high percentage (43\%) of UI may suggest a different biology of PCDLBCL-LT compared with DLBCL-NOS for which these algorithms were originally developed. Future studies need to investigate this observation with more comprehensive transcriptomic analysis, such as the EcoTyper, as recently described by Steen et al. [40].

In our cohort of PCDLBCL-LT, MYD88 and/or CD79B mutations as well as survival did not statistically differ between the $\mathrm{COO}$ subtypes defined by both algorithms. This corresponds to PCNSL, as Bödör et al. [31] also reported equal distribution of $M Y D 88$ and/or $C D 79 B$ mutations and no differences in survival between the $\mathrm{COO}$ subgroups.

While our results showed that classification as non-GCB with Hans or $\mathrm{ABC} / \mathrm{UI}$ with Lymph2Cx strongly favors a diagnosis of PCDLCBL-LT, a GCB outcome does not differentiate between PCFCL-LC and PCDLBCL-LT. Use of $\mathrm{COO}$ algorithms for this purpose should, therefore, be interpreted with caution, as incorrect interpretation may have far stretching clinical implications. For instance, PCDLBCL-LT as defined by the 2016 revised WHO classification or the 2018 update of the WHO-EORTC classification but categorized as GCB by either the Hans or Lymph2Cx algorithm may be misdiagnosed as PCFCL-LC and, subsequently, treated incorrectly as a low-grade CLBCL with radiotherapy instead of immuno-polychemotherapy.

In conclusion, our data confirm the GCB-subtype of PCFCL-LC but show that PCDLBCL-LT cases classify along the whole COO spectrum of DLBCL-NOS using the Hans and Lymph2Cx algorithms. In contrast to systemic DLBCL-NOS, the clinical relevance of COO classification in CLBCL using these algorithms is limited and cannot be used as an alternative for the current multiparameter approach in differentiation of PCDLBCL-LT and PCFCL-LC.
Supplementary Information The online version contains supplementary material available at https://doi.org/10.1007/s00428-021-03265-5.

Acknowledgements We would like to acknowledge the support provided by Dr Staudt's Laboratory at NCI/NIH Bethesda, Maryland, USA, for online analysis of Lymph2Cx raw data for $\mathrm{COO}$ characterization.

Author contribution The following authors contributed to the conception or design of the research: AS, RG, RW, PJ, MV, and JV. The following authors contributed to the collection of patient materials and clinical data: RW, KQ, EH, SW, AB, MV, and JV. The following authors contributed to the data analysis and interpretation: AS, RG, RW, TW, RE, DR, AB, AD, and JV. The following author drafted the work: AS. The following authors revised the work critically for important intellectual content: RW, PJ, KQ, CT, AD, MV, and JV. All authors reviewed the manuscript, approved the final version, and agreed to be accountable for all aspects of the work.

\section{Declarations}

Ethics approval The study was performed in accordance with the Code Proper Secondary Use of Human Tissue and to the regulations of inhouse Biobank protocol, as approved by the Medical Ethics Committee of the LUMC and the UZL.

Competing interests M.V. is a member of an entity's Board of Directors or advisory committees of the Innate Pharma safety board for IPH4102-101. The remaining authors have no relevant financial or non-financial interest to disclose.

Open Access This article is licensed under a Creative Commons Attribution 4.0 International License, which permits use, sharing, adaptation, distribution and reproduction in any medium or format, as long as you give appropriate credit to the original author(s) and the source, provide a link to the Creative Commons licence, and indicate if changes were made. The images or other third party material in this article are included in the article's Creative Commons licence, unless indicated otherwise in a credit line to the material. If material is not included in the article's Creative Commons licence and your intended use is not permitted by statutory regulation or exceeds the permitted use, you will need to obtain permission directly from the copyright holder. To view a copy of this licence, visit http://creativecommons.org/licenses/by/4.0/.

\section{References}

1. Willemze R, Cerroni L, Kempf W, Berti E, Facchetti F, Swerdlow SH, Jaffe ES (2019) The 2018 update of the WHO-EORTC classification for primary cutaneous lymphomas Blood. https://doi. org/10.1182/blood-2018-11-881268

2. Senff NJ, Hoefnagel JJ, Jansen PM, Vermeer MH, van Baarlen J, Blokx WA, Canninga-van Dijk MR, Geerts ML, Hebeda KM, Kluin PM, Lam KH, Meijer CJ, Willemze R (2007) Reclassification of 300 primary cutaneous B-Cell lymphomas according to the new WHO-EORTC classification for cutaneous lymphomas: comparison with previous classifications and identification of prognostic markers. J Clin Oncol 25:1581-1587. https://doi.org/ 10.1200/JCO.2006.09.6396

3. Willemze R, Meijer CJ, Scheffer E, Kluin PM, Van Vloten WA, Toonstra J, Van der Putte SC (1987) Diffuse large cell lymphomas 
of follicular center cell origin presenting in the skin. A clinicopathologic and immunologic study of 16 patients. Am J Pathol 126:325-333

4. Vermeer MH, Geelen FA, van Haselen CW, van Voorst Vader PC, Geerts ML, van Vloten WA, Willemze R (1996) Primary cutaneous large B-cell lymphomas of the legs. A distinct type of cutaneous B-cell lymphoma with an intermediate prognosis. Dutch Cutaneous Lymphoma Working Group Arch Dermatol 132:1304-1308

5. Willemze R, Kerl H, Sterry W, Berti E, Cerroni L, Chimenti S, Diaz-Perez JL, Geerts ML, Goos M, Knobler R, Ralfkiaer E, Santucci M, Smith N, Wechsler J, van Vloten WA, Meijer CJ (1997) EORTC classification for primary cutaneous lymphomas: a proposal from the Cutaneous Lymphoma Study Group of the European Organization for Research and Treatment of Cancer. Blood 90:354-371

6. Willemze R, Jaffe ES, Burg G, Cerroni L, Berti E, Swerdlow SH, Ralfkiaer E, Chimenti S, Diaz-Perez JL, Duncan LM, Grange F, Harris NL, Kempf W, Kerl H, Kurrer M, Knobler R, Pimpinelli N, Sander C, Santucci M, Sterry W, Vermeer MH, Wechsler J, Whittaker S, Meijer CJ (2005) WHO-EORTC classification for cutaneous lymphomas. Blood 105:3768-3785. https://doi.org/10. 1182/blood-2004-09-3502

7. Koens L, Vermeer MH, Willemze R, Jansen PM (2010) IgM expression on paraffin sections distinguishes primary cutaneous large B-cell lymphoma, leg type from primary cutaneous follicle center lymphoma. Am J Surg Pathol 34:1043-1048. https://doi. org/10.1097/PAS.0b013e3181e5060a

8. Koens L, Zoutman WH, Ngarmlertsirichai P, Przybylski GK, Grabarczyk P, Vermeer MH, Willemze R, Jansen PM, Schmidt CA, Tensen CP (2014) Nuclear factor-kappaB pathway-activating gene aberrancies in primary cutaneous large B-cell lymphoma, leg type. J Invest Dermatol 134:290-292. https://doi.org/10.1038/jid.2013. 265

9. Menguy S, Gros A, Pham-Ledard A, Battistella M, Ortonne N, Comoz F, Balme B, Szablewski V, Lamant L, Carlotti A, Lorton MH, de Muret A, Le Gall F, Franck F, Croue A, Cappellen D, Beylot-Barry M, Merlio JP, Vergier B (2016) MYD88 somatic mutation is a diagnostic criterion in primary cutaneous large B-Cell lymphoma. J Invest Dermatol 136:1741-1744. https://doi. org/10.1016/j.jid.2016.04.018

10. Pham-Ledard A, Cappellen D, Martinez F, Vergier B, BeylotBarry M, Merlio JP (2012) MYD88 somatic mutation is a genetic feature of primary cutaneous diffuse large B-cell lymphoma, leg type. J Invest Dermatol 132:2118-2120. https://doi.org/10.1038/ jid.2012.102

11. Senff NJ, Zoutman WH, Vermeer MH, Assaf C, Berti E, Cerroni L, Espinet B, de Misa Cabrera RF, Geerts ML, Kempf W, Mitchell TJ, Paulli M, Petrella T, Pimpinelli N, Santucci M, Whittaker SJ, Willemze R, Tensen CP (2009) Fine-mapping chromosomal loss at $9 \mathrm{p} 21$ : correlation with prognosis in primary cutaneous diffuse large B-cell lymphoma, leg type. J Invest Dermatol 129:11491155. https://doi.org/10.1038/jid.2008.357

12. Alizadeh AA, Eisen MB, Davis RE, Ma C, Lossos IS, Rosenwald A, Boldrick JC, Sabet H, Tran T, Yu X, Powell JI, Yang L, Marti GE, Moore T, Hudson J Jr, Lu L, Lewis DB, Tibshirani R, Sherlock G, Chan WC, Greiner TC, Weisenburger DD, Armitage JO, Warnke R, Levy R, Wilson W, Grever MR, Byrd JC, Botstein D, Brown PO, Staudt LM (2000) Distinct types of diffuse large B-cell lymphoma identified by gene expression profiling. Nature 403:503-511. https://doi.org/10.1038/35000501

13. Hans CP, Weisenburger DD, Greiner TC, Gascoyne RD, Delabie J, Ott G, Muller-Hermelink HK, Campo E, Braziel RM, Jaffe ES, Pan Z, Farinha P, Smith LM, Falini B, Banham AH, Rosenwald A, Staudt LM, Connors JM, Armitage JO, Chan WC (2004)
Confirmation of the molecular classification of diffuse large B-cell lymphoma by immunohistochemistry using a tissue microarray. Blood 103:275-282. https://doi.org/10.1182/blood-2003-05-1545

14. Scott DW, Mottok A, Ennishi D, Wright GW, Farinha P, BenNeriah S, Kridel R, Barry GS, Hother C, Abrisqueta P, Boyle M, Meissner B, Telenius A, Savage KJ, Sehn LH, Slack GW, Steidl C, Staudt LM, Connors JM, Rimsza LM, Gascoyne RD (2015) Prognostic significance of diffuse large B-cell lymphoma cell of origin determined by digital gene expression in formalin-fixed paraffin-embedded tissue biopsies. J Clin Oncol 33:2848-2856. https://doi.org/10.1200/JCO.2014.60.2383

15. Scott DW, Wright GW, Williams PM, Lih CJ, Walsh W, Jaffe ES, Rosenwald A, Campo E, Chan WC, Connors JM, Smeland EB, Mottok A, Braziel RM, Ott G, Delabie J, Tubbs RR, Cook JR, Weisenburger DD, Greiner TC, Glinsmann-Gibson BJ, Fu K, Staudt LM, Gascoyne RD, Rimsza LM (2014) Determining cell-of-origin subtypes of diffuse large B-cell lymphoma using gene expression in formalin-fixed paraffin-embedded tissue. Blood 123:1214-1217. https://doi.org/10.1182/blood-2013-11-536433

16. Hoefnagel JJ, Dijkman R, Basso K, Jansen PM, Hallermann C, Willemze R, Tensen CP, Vermeer MH (2005) Distinct types of primary cutaneous large B-cell lymphoma identified by gene expression profiling. Blood 105:3671-3678. https://doi.org/10. 1182/blood-2004-04-1594

17. Schrader AMR, Jansen PM, Vermeer MH, Kleiverda JK, Vermaat JSP, Willemze R (2018) High incidence and clinical significance of MYC rearrangements in primary cutaneous diffuse large B-cell lymphoma, leg type. Am J Surg Pathol 42:1488-1494. https://doi. org/10.1097/PAS.0000000000001132

18. Swerdlow SH (ed) (2017) WHO classification of tumours of haematopoietic and lymphoid tissues. IARC, Lyon, Pages

19. van Eijk R, Stevens L, Morreau H, van Wezel T (2013) Assessment of a fully automated high-throughput DNA extraction method from formalin-fixed, paraffin-embedded tissue for KRAS, and BRAF somatic mutation analysis. Exp Mol Pathol 94:121125. https://doi.org/10.1016/j.yexmp.2012.06.004

20. de Groen RAL, van Eijk R, Bohringer S, van Wezel T, Raghoo R, Ruano D, Jansen PM, Briaire-de Bruijn I, de Groot FA, Kleiverda K, Te Boome L, Terpstra V, Levenga H, Nicolae A, Posthuma EFM, Focke-Snieders I, Hardi L, den Hartog WCE, Bohmer LH, Hogendoorn PCW, van den Berg A, Diepstra A, Nijland M, Lugtenburg PJ, Kersten MJ, Pals ST, Veelken H, Bovee J, Cleven AHG, Vermaat JSP (2021) Frequent mutated B2M, EZH2, IRF8, and TNFRSF14 in primary bone diffuse large B-cell lymphoma reflect a GCB phenotype Blood Adv 5:3760-3775. https://doi.org/ 10.1182/bloodadvances.2021005215

21. Schemper M, Smith TL (1996) A note on quantifying follow-up in studies of failure time. Control Clin Trials 17:343-346

22. Menguy S, Beylot-Barry M, Marie P, Pham Ledard A, Frison E, Comoz F, Battistella M, Szablewski V, Balme B, Croue A, Franck F, Ortonne N, Tournier E, Lamant L, Carlotti A, De Muret A, Le Gall F, Lorton MH, Merlio JP, Vergier B (2019) Primary cutaneous large B-cell lymphomas: relevance of the 2017 WHO classification histopathology. https://doi.org/10.1111/his.13832

23. Oschlies I, Kohler CW, Szczepanowski M, Koch K, Gontarewicz A, Metze D, Hillen U, Richter J, Spang R, Klapper W (2017) Spindle-cell variants of primary cutaneous follicle center B-cell lymphomas are germinal center B-cell lymphomas by gene expression profiling using a formalin-fixed paraffin-embedded specimen. J Invest Dermatol 137:2450-2453. https://doi.org/10. 1016/j.jid.2017.06.016

24. Felcht M, Klemke CD, Nicolay JP, Weiss C, Assaf C, Wobser M, Schlaak M, Hillen U, Moritz R, Tantcheva-Poor I, Nashan D, Beyer M, Dippel E, Muller CSL, Sachse MM, Meiss F, Geraud C, Marx A, Goerdt S, Geissinger E, Kempf W (2019) Primary 
cutaneous diffuse large B-cell lymphoma, NOS and leg type: clinical, morphologic and prognostic differences J Dtsch Dermatol Ges. https://doi.org/10.1111/ddg.13773

25. Elder DE (ed) (2018) WHO classification of skin tumours. IARC, Lyon, Pages

26. Kraan W, Horlings HM, van Keimpema M, Schilder-Tol EJ, Oud ME, Scheepstra C, Kluin PM, Kersten MJ, Spaargaren M, Pals ST (2013) High prevalence of oncogenic MYD88 and CD79B mutations in diffuse large B-cell lymphomas presenting at immuneprivileged sites. Blood Cancer J 3:e139. https://doi.org/10.1038/ bcj.2013.28

27. Kraan W, van Keimpema M, Horlings HM, Schilder-Tol EJ, Oud ME, Noorduyn LA, Kluin PM, Kersten MJ, Spaargaren M, Pals ST (2014) High prevalence of oncogenic MYD88 and CD79B mutations in primary testicular diffuse large B-cell lymphoma Leukemia 28:719-720. https://doi.org/10.1038/leu.2013.348

28. Schrader AMR, Jansen PM, Willemze R, Vermeer MH, CletonJansen AM, Somers SF, Veelken H, van Eijk R, Kraan W, Kersten MJ, van den Brand M, Stevens WBC, de Jong D, Abdul Hamid M, Tanis BC, Posthuma EFM, Nijland M, Diepstra A, Pals ST, Cleven AHG, Vermaat JSP (2018) High prevalence of MYD88 and CD79B mutations in intravascular large B-cell lymphoma. Blood 131:2086-2089. https://doi.org/10.1182/blood-2017-12-822817

29. Lucioni M, Pescia C, Bonometti A, Fraticelli S, Moltrasio C, Ramponi A, Riboni R, Roccio S, Ferrario G, Arcaini L, Goteri G, Berti E, Paulli M (2021) Double expressor and double/triple hit status among primary cutaneous diffuse large B-cell lymphoma: a comparison between leg type and not otherwise specified subtypes. Hum Pathol 111:1-9. https://doi.org/10.1016/j.humpath. 2021.01.006

30. Pasqualucci L (2019) Molecular pathogenesis of germinal centerderived B cell lymphomas. Immunol Rev 288:240-261. https:// doi.org/10.1111/imr.12745

31. Bodor C, Alpar D, Marosvari D, Galik B, Rajnai H, Batai B, Nagy A, Kajtar B, Burjan A, Deak B, Schneider T, Alizadeh H, Matolcsy A, Brandner S, Storhoff J, Chen N, Liu M, Ghali N, Csala I, Bago AG, Gyenesei A, Reiniger L (2020) Molecular subtypes and genomic profile of primary central nervous system lymphoma. J Neuropathol Exp Neurol 79:176-183. https://doi.org/10.1093/ jnen/nlz125

32. Cheah CY, Wirth A, Seymour JF (2014) Primary testicular lymphoma Blood 123:486-493. https://doi.org/10.1182/ blood-2013-10-530659

33. Twa DDW, Mottok A, Savage KJ, Steidl C (2018) The pathobiology of primary testicular diffuse large B-cell lymphoma: implications for novel therapies. Blood Rev 32:249-255. https://doi.org/ 10.1016/j.blre.2017.12.001

34. Villa D, Tan KL, Steidl C, Ben-Neriah S, Al Moosawi M, Shenkier TN, Connors JM, Sehn LH, Savage KJ, Scott DW, Gascoyne RD, Slack GW (2019) Molecular features of a large cohort of primary central nervous system lymphoma using tissue microarray. Blood Adv 3:3953-3961. https://doi.org/10.1182/bloodadvan ces.2019000989
35. Montesinos-Rongen M, Brunn A, Bentink S, Basso K, Lim WK, Klapper W, Schaller C, Reifenberger G, Rubenstein J, Wiestler OD, Spang R, Dalla-Favera R, Siebert R, Deckert M (2008) Gene expression profiling suggests primary central nervous system lymphomas to be derived from a late germinal center B cell. Leukemia 22:400-405. https://doi.org/10.1038/sj.leu.2405019

36. Wright G, Tan B, Rosenwald A, Hurt EH, Wiestner A, Staudt LM (2003) A gene expression-based method to diagnose clinically distinct subgroups of diffuse large B cell lymphoma. Proc Natl Acad Sci U S A 100:9991-9996. https://doi.org/10.1073/pnas. 1732008100

37. Rubenstein JL, Fridlyand J, Shen A, Aldape K, Ginzinger D, Batchelor T, Treseler P, Berger M, McDermott M, Prados M, Karch J, Okada C, Hyun W, Parikh S, Haqq C, Shuman M (2006) Gene expression and angiotropism in primary CNS lymphoma. Blood 107:3716-3723. https://doi.org/10.1182/ blood-2005-03-0897

38. Chapuy B, Stewart C, Dunford AJ, Kim J, Kamburov A, Redd RA, Lawrence MS, Roemer MGM, Li AJ, Ziepert M, Staiger AM, Wala JA, Ducar MD, Leshchiner I, Rheinbay E, Taylor-Weiner A, Coughlin CA, Hess JM, Pedamallu CS, Livitz D, Rosebrock D, Rosenberg M, Tracy AA, Horn H, van Hummelen P, Feldman AL, Link BK, Novak AJ, Cerhan JR, Habermann TM, Siebert R, Rosenwald A, Thorner AR, Meyerson ML, Golub TR, Beroukhim R, Wulf GG, Ott G, Rodig SJ, Monti S, Neuberg DS, Loeffler M, Pfreundschuh M, Trumper L, Getz G, Shipp MA (2018) Molecular subtypes of diffuse large B cell lymphoma are associated with distinct pathogenic mechanisms and outcomes. Nat Med 24:679-690. https://doi.org/10.1038/s41591-018-0016-8

39. Schmitz R, Wright GW, Huang DW, Johnson CA, Phelan JD, Wang JQ, Roulland S, Kasbekar M, Young RM, Shaffer AL, Hodson DJ, Xiao W, Yu X, Yang Y, Zhao H, Xu W, Liu X, Zhou B, Du W, Chan WC, Jaffe ES, Gascoyne RD, Connors JM, Campo E, Lopez-Guillermo A, Rosenwald A, Ott G, Delabie J, Rimsza LM, TayKuang Wei K, Zelenetz AD, Leonard JP, Bartlett NL, Tran B, Shetty J, Zhao Y, Soppet DR, Pittaluga S, Wilson WH, Staudt LM (2018) Genetics and pathogenesis of diffuse large B-cell lymphoma. N Engl J Med 378:1396-1407. https://doi.org/10.1056/ NEJMoa1801445

40. Steen CB, Luca BA, Esfahani MS, Azizi A, Sworder BJ, Nabet BY, Kurtz DM, Liu CL, Khameneh F, Advani RH, Natkunam Y, Myklebust JH, Diehn M, Gentles AJ, Newman AM, Alizadeh AA (2021) The landscape of tumor cell states and ecosystems in diffuse large B cell lymphoma. Cancer Cell 39(1422-1437):e1410. https://doi.org/10.1016/j.ccell.2021.08.011

Publisher's note Springer Nature remains neutral with regard to jurisdictional claims in published maps and institutional affiliations. 